FABULARIO 


\section{Poemas escogidos ${ }^{*}$}

Por Opal Palmer Adisa ${ }^{1}$

\section{El escape de la escritora}

\section{I}

deambulando por los bosques

con el tiempo limpio del día

rodeamos

el mismo árbol

cuatro veces

antes de reconocerlo

la zarza crujiente

bajo nuestros pies

nos llamaba

como las voces

de nuestros padres

que pretendíamos no escuchar

pude olerlo

Tamarindo

Pude olerme

Casabe

eramos amigos

* Traducción especial para Visitas al patio del inglés al español por Marcelo Cabarcas. ${ }^{1}$ Nacida en Jamaica, en 1957, es una reconocida poeta, narradora y crítica. Entre sus obras destacan: Pina, The many eyed fruit (1985), Bake-face and other Guava stories (1986) y Tamarind and mango women (1992). Ha sido ganadora del Pushcart Prize (1987) y del PEN Oakland/Josephine Miles Literary Award (1992). Su trabajo ha sido ampliamente antologado en Norteamérica, Europa y el Caribe. Actualmente se desempeña como profesora de literatura y escritura creativa en el California College of Arts. 


\section{The Writer's Escape}

\section{I}

trekking in the woods time of day

wiped clean

we circled

around the same tree four times

before recognition

the crunch of bramble underfoot

called to us

like our parents'

voices we

pretended not to hear

i smelled him

tamarind

i smelled myself

cassava

were we

friends 


\section{II}

En casa

oculta detrás del

mueble de radio

vacío sobre el armario

mi nombre

ya no me pertenecía

no me reclamaba

a mí misma

un desfile de imágenes

en mi cabeza

yo era mi propia amiga

\section{III}

Prisioneros prófugos

se esparcieron por los cañizales

a lo largo de la carretera

se le advirtió a las mujeres

no caminar solas

sin decirles

lo que esos hombres perversos

eran capaces de hacer

en algún lugar solitario

del que jamás me atrevería a hablar

quería saber

lo que me harían

así que fui al borde de los cañizales

con la esperanza de sostener

el rostro de uno de esos prófugos

en mis pequeñas manos

para que me contara

de primera mano

lo que sintió cuando los ramales del azote

castigaban

su espalda desnuda 
II

at home

hidden behind the

empty stereo box

on top of the closet

i did not own

my name

i did not

claim myself

a track-meet of images

inside my head

i was my own

friend

III

escaped prisoners

were spotted in the cane-fields

that lined the main road

women were warned

not to walk alone

no telling

what those wicked men

may do

in some private

i would-never-dear-to-speak

space i wanted to know

what they would do

i lingered at the edge of the cane-fields

hoping to hold

one of those escapee's face

in my small hands

and have him tell me

first-hand account

how it felt when

the cat-o-nine-tail

was brought down

on his bare behind 


\section{Un Arawak habla}

Para que quede constancia

No fue

con ojos inocentes

que yo el indígena

de estas orillas

observé

tu arribo

Tu llegada

por largo tiempo profetizada

A menudo al descamar un pez sus entrañas Sangrarán tus dedos

Siempre

estaré aquí

si dudas de mi

pon tu oído

sobre el suelo

La redondez de la luna ciega al sol pero no puede negar su existencia 


\section{An Arawak Speaks}

for the record

it was not

with innocent eyes

i the indigenous

of these shores

watched

your arrival

your coming was long prophesized

\section{often when scaling a fish its gill will bleed your fingers}

i'll always

be here

if you doubt me

place your ear

to the ground

the moon's fullness blinds the sun but cannot deny its existence 


\section{Bruk-Up ${ }^{2}$}

golpe golpe golpe

un canto interminable

recorre la tierra

la pala golpe

usada contra la roca

golpe golpe

contra la grava también contra la marga

la semilla arrojada

también la sal

que fortalece las raíces

golpe golpe

paul metido en sus asuntos

su boca torcida murmurando

reclamos

entonces la tierra le habló

toma la biblia con tu derecha

$Y$ ponla en tu izquierda

contemplaba

el suelo y las escrituras

mientras el viento continuaba hablándole

escucha paul le decía

él no estaba listo para escuchar

bogle eres único

te ruego y te ruego

por un momento de atención

empezaron a susurrar los arboles

no habrá suficiente comida

por aquel sendero

los hombres marchando en fila

marchando en grupos a paso largo

2 "Bruk-Up" es un estilo de baile jamaiquino que acompaña al dancehall y al reggae, y que dio origen al "flexing" neoyorquino (N. del T.) 


\title{
1865 Bruk-Up
}

\author{
thud thud thud \\ the endless dirge \\ to wind the land \\ to use thud \\ shovel against rock \\ thud thud \\ gravel too marl \\ to bed seed \\ too salt \\ to strengthen roots \\ thud thud
}

paul was minding them business his mouth twisting how to frame them demands when the earth spoke pick up de bible in yu right hand and them plan in yu left

he was the studying the soil and scriptures but the wind kept talking to him listen paul the voice said

he wasn't ready to hear bogle is you same one $i$ and $i$ begging you ear for a moment the trees began to whistle never enough food from way yonder them marching walking single file marching in groups striding machetes perched on their shoulders tip pointed backwards and is now he asking for guidance is now he take up their woes like wasp nest 
sus machetes colgados sobre sus hombros

inclinados hacia atrás

ahora él les pide guiarlos

ahora él arroja

su congoja como un nido de avispas

la misma iglesia bautista

ellos se recuestan de nuevo

él quien predica él quien lidera

su boca llena de palabras

yo sé porque

en stony gut ${ }^{3}$

ninguna familia se alimenta

de las costillas flacas

de la colina

de la tierra dura

como coco seco

eso voy a decirles

45 millas hasta spanish town

él viajó

bogle parado en firme como

vara alta de bambú

sus palabras

como banano lacatan

derritiéndose en la boca

pero entonces muchos oídos sordos

el regresó

con la lengua inflamada

nada era distinto

el pidió a

400 valientes con él

con sus caras como batata amarilla

marcharon al palacio de justicia de morant bay

400 valientes un once de octubre

${ }^{3}$ Stony gut es el lugar de nacimiento de Paul Bogle, uno de los héroes nacionales de Jamaica. La villa fue también el lugar donde practicó su ministerio bautista y desde donde lideró la rebelión de Morant Bay de 1865, episodio histórico que da origen al poema. (N. del. T.). 
his same baptist church

they come lean up against

he preacher he leader

mouth full of words

i know why it name

stony gut

no family can feed

from the mawga ribs

of a hillside

the land hard

like dry coconut

that's what igo tell them

45 miles to spanish town

he trekked

bogle stand like

tall bamboo

his words

like lacatan banana

that melt in the mouth

but dem tun deaf ears

he come back

with a swollen tongue

still same way

he petitioned

400 strong with him

them faces yellow yam

them march to morant bay court house

400 strong on october 11

crying food water

school for our children

not even phlegm

the soil can cough up

but soldiers chase and beat them 
gritando por agua por comida

por escuelas para sus niños

ni siquiera catarro

puede escupir la tierra

pero los soldados los persiguieron y golpearon

así que la arrasaron

hasta sus mismos cimientos

ahora bogle está en el meollo del asunto

y la voz continua diciéndole

adelante hombre adelante

él ocupándose de los problemas de todos

y su amigo

g w Gordon

hablando también por todos

así que lo colgaron

bogle dejó la biblia en el suelo

Y con ambas manos recogió la lucha

se levantó una mañana de octubre

con la garganta seca

y él supo y él no supo

ni siquiera cuando la soga hirió su cuello

Otros 430 con él

los soldados masacraron

su frustrada ira

atrapados entre las llamas

1000 hogares calcinados

ante el dolor resignado

oh morant bay

golpe

vulgar paul bogle

golpe

vaya morant bay

golpe

la roca-piedra bebe la sangre 
so dem bun it down

right to the ground

now bogle in the thick of things

and the voice still say

go on man presson

he minding them business

and his friend

g w gordon

chatting up for them too

so dem hang him

bogle put down the bible

and pick up de struggle in both hands

he wake one october morning

with dry throat

he did know and he didn't know

not even when the rope caressed

his neck

430 others with him

soldiers slaughtered

their frustrated anger

caught in flames

1000 homes burnt

before them sorrow mek news

oh morant bay

thud

lawd paul bogle

thud

wow morant bay

thud

rock-stone drink blood 